\title{
ESSAY
}

\section{REPLACING INDEPENDENT COUNSELS WITH CONGRESSIONAL INVESTIGATIONS}

\author{
MICHAEL B. RAPPAPORT ${ }^{\dagger}$
}

\section{INTRODUCTION}

Last year, the Independent Counsel statute ${ }^{1}$ expired and it now appears there is a good chance that the statute will not be reenacted. This is a welcome development, because the statute suffered from many grave constitutional and policy defects. But if independent counsels are eliminated, with what will we replace them? For the last two decades, the nation has relied upon Independent Counsels to police wrongdoing by high executive branch officials. Prior to that, the country used various institutions that Congress judged to be inadequate when it chose to adopt the Independent Counsel statute. Unfortunately, it is not easy to design an institution that effectively investigates the executive but does not overreach.

Most proposals for replacing the Independent Counsel statute use some part of the executive branch to investigate executive misconduct. $^{2}$ Some of these proposals rely on officials, like the Independent Counsel, who are independent of presidential control. Such officials, however, are constitutionally problematic and not accountable to the electorate. Other proposals employ officials who are subject to the President's direction, but these approaches cannot ensure that vigorous and impartial investigations will be conducted.

Instead of relying on the executive branch to investigate, I propose that we return to the system adopted by the Framers, in which

$\dagger$ Professor of Law, University of San Diego School of Law. I would like to thank Larry Alexander, Stuart Benjamin, Shaun Martin, John McGinnis, Sai Prakash, and Mike Ramsey for their helpful comments. I am also grateful for the comments made when this paper was given at a Federalist Society panel discussion in the Senate Office Building in April 1999.

28 U.S.C. $\$ \S 591-599$ (1994).

${ }^{2}$ See infra notes $26-30$ and accompanying text (discussing the various types of proposals mentioned). 
Congress investigates executive wrongdoing. The Constitution assigns to Congress the power to investigate and remove executive officials through its impeachment and oversight powers. 3 Under a congressional investigation system, a congressional committee would uncover executive misconduct and then issue public reports documenting it. Disclosing this information to the public would help hold the executive politically accountable for her misbehavior. In many cases, the disclosures would lead the President to dismiss the responsible official. If the official were not removed, Congress could always use the information that it uncovered as a basis for impeachment.

It is true that congressional investigations presently suffer from certain defects. Congressional investigations are often viewed as excessively partisan, which has diminished the credibility of the information they have uncovered. Moreover, congressional committees frequently lack the powers needed to conduct effective investigations, including the power to adequately enforce their subpoenas and to delegate to their staffs the authority to question witnesses who are under oath.

But these problems can be solved. To prevent the investigative committee from excessive partisanship, Congress should adopt a new method for appointing members of the committee. Congressional rules should require the Democrats to choose the Republican members of the committee and the Republicans to choose the Democratic members. Under this appointment method, each party would have an incentive to select the legislators from the opposing party who it believed would most often act based on the evidence rather than on political considerations. Each party also would not appoint members of the opposing party who were political extremists.

The investigative committee should also be given additional powers. Congress could provide the committee with adequate authority to enforce committee subpoenas by authorizing it to bring civil lawsuits for this purpose. The committee should also be permitted to delegate to its staff the power to question witnesses who are under oath. Delegation of this power would reduce the burdens on committee members, who have many other legislative responsibilities. Delegation would also allow for more effective investigations, because the staff would have expertise and experience that many members lack.

${ }^{3}$ See U.S. CONST. art. I, $\S \S 2-3$ (granting the House of Representatives the power to impeach and granting the Senate the power to try impeachments); McGrain v. Daugherty, 273 U.S. 135, 173-75 (1927) (holding that Congress possesses the power to "exact information in aid of the legislative function"). 
This congressional investigation proposal has many virtues. First, the proposal would establish a fully constitutional procedure. It would not, like the Independent Counsel statute, need to bend or break the Constitution in order to erect an effective investigative structure. Second, the proposal would place the power of investigation in officials who are accountable to the electorate but who are entirely independent of the President-an important ideal that no system of investigations by the executive branch can achieve. Finally, the proposal would create a fair investigative process. Unlike the Independent Counsel statute, the proposal would not provide investigators with an incentive to overreach and could not be easily used as a political weapon against one's enemies.

This Essay proceeds in four parts. Part I describes the serious problems that have plagued the Independent Counsel statute and which would to some extent afflict all investigations by executive branch officials. Part II describes my proposal for congressional investigations, explaining how the system would work and describing the changes in existing practice it would require. Part III argues that the congressional investigation proposal would be superior to investigations by the executive branch. Finally, Part IV responds to objections and addresses additional aspects of the proposal.

\section{INVESTIGATIONS BY THE EXECUTIVE BRANCH}

\section{A. Problems with the Independent Counsel Statute}

The Independent Counsel statute suffers from several serious problems. Perhaps the most basic problem with the statute is that it is unconstitutional. This might seem to be a peculiar claim, as the Supreme Court approved the constitutionality of the statute in Morrison v. Olson. ${ }^{4}$ But the meaning of the Constitution cannot be the exclusive preserve of the Supreme Court. It is essential that the public be able to criticize and disagree with Supreme Court constitutional interpretations, especially those like Morrison, which ignore text, history, and precedent.

There are two fundamental constitutional flaws with the statute. The first involves the method of appointing the Independent Counsel. Under the statute, the Independent Counsel is appointed by a three-judge panel. ${ }^{5}$ The Appointments Clause of the Constitution re-

\footnotetext{
487 U.S. $654,696-97$ (1988).

${ }^{5}$ See 28 U.S.C. $§ 593$ (1994).
} 
quires that executive officers be appointed by the President with the advice and consent of the Senate, but it also allows Congress to assign the appointment of inferior officers to the judiciary. ${ }^{6}$ Thus, the judicial appointment of the Independent Counsel will be constitutional only if the Independent Counsel is classified as an inferior officer.

One cannot plausibly argue, however, that the Independent Counsel is an inferior officer. The Independent Counsel exercises important executive authority-the power to investigate and prosecute high executive branch officials, including the President-and is not subject to the direction of any other official. An officer without a superior cannot be inferior. ${ }^{7}$ Thus, the Independent Counsel is a noninferior officer who must be appointed by the President with the advice and consent of the Senate. To conclude that the Independent Counsel was an inferior officer, the Court in Morrison was forced to ignore this central point. Instead, the Court adopted a vague and unpersuasive balancing test that allowed it to reach virtually any conclusion it desired. ${ }^{8}$ Happily, the Court may now have recognized its mistake, because all nine Justices have recently joined opinions that interpreted "inferior officer" more appropriately."

The second constitutional flaw is that the statute deprives the President of the power to direct and remove the Independent Counsel. This insulation is obviously necessary if the Independent Counsel is to be independent of the President. The problem, however, is that the Constitution is best read as providing the President with the power to direct and remove all executive branch officials. ${ }^{10}$ Although the Supreme Court departed from that interpretation in the $1930 \mathrm{~s},{ }^{11}$ it had for fifty years interpreted the Constitution as permitting Congress to make quasi-legislative and quasi-judicial officials independent of

${ }^{6}$ U.S. CONST. art. II, § 2, cl. 2.

7 See Morrison, 487 U.S. at 719-23 (Scalia, J., dissenting) (arguing that under the Appointments Clause, a necessary condition for an inferior officer is that he be subordinate to another officer).

${ }^{8}$ See id. at $671-73$ (relying on a four-factor test without explaining the weights to be attached to the different factors).

${ }^{9}$ See, e.g., Edmond v. United States, 520 U.S. 651, 662-63 (1997); id. at 666-67 (Souter, J., concurring in part and concurring in the judgment) (agreeing with the majority that "one who has no superior is not an inferior officer").

${ }^{10}$ See Myers v. United States, 272 U.S. 52, 163-64 (1926); Steven G. Calabresi \& Saikrishna B. Prakash, The President's Power To Execute the Laws, 104 YALE L.J. 541, 549 (1994) (arguing that the Constitution authorizes the President to direct all executive officials).

"See Humphrey's Ex'r v. United States, 295 U.S. 602, 627-28 (1935) (limiting the holding of Myers to "purely executive officers"). 
the President, but as requiring that the President have control over

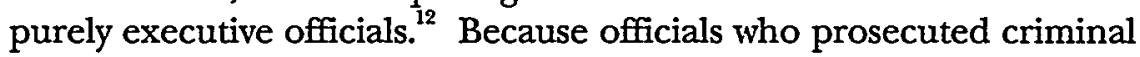
cases were purely executive officers, the prevailing constitutional doctrine when Morrison was decided required that the Independent Counsel be subject to presidential direction. Nonetheless, in a single paragraph of the Morrison opinion, the Supreme Court swept away fifty years of constitutional interpretation without the slightest effort to justify its action. ${ }^{13}$ Even worse, the Supreme Court's new interpretation was entirely devoid of principle, leaving the question of whether an executive official may be made independent to the unlimited discretion of the Supreme Court.

In the years since Morrison was decided, the Independent Counsel statute has become less popular, and the Court's decision has been increasingly criticized. ${ }^{14}$ Those who previously defended the opinion as a wise constitutional accommodation of the need for executive accountability are now more apt to recognize that Morrison's departures from prior constitutional principle have corrupted the investigative process. ${ }^{15}$ In time, Morrison may even come to be viewed for what I have always believed it to be: a cynical opinion adopted by a Court that believed that the elite's (mistaken) view about what was good public policy should take priority over the Constitution.

${ }^{12}$ See Morrison, 487 U.S. at 723-27 (Scalia, J., dissenting).

${ }^{13}$ See id. at 689-91.

14 See, e.g., Akhil Reed Amar, Now Playing: A Constitutional Nightmare, WASH. PosT, Sept. 20, 1998, at Cl (blaming the Independent Counsel statute for "the unconstitutional mess we find ourselves in"); Anthony Lewis, Abuse of Power, N.Y. TIMES, Feb. 2, 1998, at A23 (describing the Independent Counsel statute as a threat to checks and balances); Anthony Lewis, Independent Counsel Act Must Go, TIMES-PiCAYUNE (New Orleans), Feb. 24, 1999, at B7 [hereinafter Lewis, Independent Counsel Act Must Go] (arguing that experience with independent counsel investigations has vindicated the dissenting opinion of Justice Scalia in Morrison); Jeffrey Rosen, Kenneth Starr, Trapped, N.Y. TIMES, June 1, 1997 (Magazine), at 42 (stating that the Independent Counsel statute "creates a free-floating prosecutor with an ever-expanding mandate, unconstrained by time, money or political accountability"); Cass R. Sunstein, Unchecked and Unbalanced: Why the Independent Counsel Act Must Go, AM. PROSPECT, May-June 1998, at 20, 20 (calling the Independent Counsel statute "one of the most ill-conceived pieces of legislation in the last quarter century," for the statute creates "dangerous incentives" for both the Independent Counsel and Congress); Benjamin Wittes, $A$ Kiss of Death for Independent Counsels, WASH. POST, Aug. 11, 1998, at A21 (arguing that the Independent Counsel statute "erodes[s] the President's legitimate powers").

${ }^{15}$ See Editorial, Reinventing Independent Counsel, WASH. POST, Jan. 19, 1998, at A24; Linda Greenhouse, Ethics in Government: The Price of Good Intentions, N.Y. TIMES, Feb. 1, $1998, \S 4$, at 1 (noting that Democrats, who once praised Morrison, have now found "an eerie prescience" in Justice Scalia's dissent); Lewis, Independent Counsel Act Must Go, supra note 14. 
In addition to its constitutional infirmities, the Independent Counsel statute suffers from serious policy defects. First, the statute unfairly provides independent counsels with an incentive to find that the person being investigated has engaged in misconduct. ${ }^{16}$ Because an Independent Counsel usually has one principal target, she will often be judged a failure if she does not uncover wrongdoing sufficient for an indictment. By contrast, an ordinary prosecutor has less incentive to indict any particular individual since she will investigate many people and will be judged on her overall performance. Moreover, the Independent Counsel will have essentially unlimited time and resources to uncover wrongdoing by the target, while an ordinary prosecutor must allocate her time and resources among the many cases that come within her purview.

A second problem is that independent counsels exercise significant discretion but are not accountable to the electorate. Independent counsels perform important duties that involve a substantial amount of policymaking discretion, including deciding whether certain conduct by an official warrants an indictment. In a democracy, persons who exercise such discretion are generally made accountable to the public. Thus, Congress and the President stand for election, and many executive officials take direction from the President. Independent counsels, however, have virtually no accountability because they are appointed by judges, take orders from no one, and can be removed only for cause. ${ }^{17}$

${ }^{16}$ See Morrison, 487 U.S. at 731-32 (Scalia, J., dissenting) (arguing that due to a lack of "multiple responsibilities," the Independent Counsel would pursue matters an ordinary prosecutor would not); Cass R. Sunstein, Bad Incentives and Bad Institutions, 86 GEO. L.J. 2267, 2279-80 (1998) ("[T] he Act creates a strong incentive to focus intensely on particular persons....").

${ }^{17}$ It might be objected that judges in a democracy also exercise significant policymaking discretion even though they are often not accountable to the public. The discretion exercised by judges, however, is distinguishable from that of independent counsels. First, judicial power was traditionally understood not to involve policymaking. See 1 WIILIAM BLACRSTONE, COMMENTARIES *69-71 (stating that the judicial branch is "not delegated to pronounce a new law, but to maintain and expound the old one"); THE FEDERAIIST NO. 78, at 465 (Alexander Hamilton) (Clinton Rossiter ed., 1961). In more recent generations, especially since the advent of Legal Realism, the practice and understanding of judicial power has come to accept more judicial policymaking, but even this power is subject to significant limits. Judges do not generally exercise naked policy discretion, but claim to be implementing values established by others. Moreover, judges only exercise limited or interstitial discretion, within the gaps of decisions made by others. Finally, this judicial discretion is limited by the judicial process, in which judicial decisions are justified in written opinions, reviewed on appeal, and (at the highest levels) are made only by multimember panels. By contrast, independent counsels are exercising a power which has traditionally been held by po- 
The Independent Counsel's lack of accountability is not merely a problem of democratic theory, but also of democratic practice. Because the Independent Counsel is unconstrained by the fundamental democratic check on policymaking-having to stand for electionthere is a significant danger that she will behave unreasonably. ${ }^{18}$ The Independent Counsel's lack of accountability also deprives her of the political legitimacy that is crucial to the performance of her duties. The main claim to legitimacy that the Independent Counsel has is political independence or impartiality. ${ }^{19}$ But when this impartiality is seriously questioned-as Kenneth Starr's was during his investigation of President Clinton-that claim to legitimacy can easily evaporate. By contrast, an Independent Counsel who was accountable to the electorate, or to someone who had to face the electorate, could defend himself as having been authorized by the people.

The third policy defect of the Independent Counsel statute is that it employs a criminal prosecution model to monitor and discipline executive branch misconduct. ${ }^{20} \mathrm{~A}$ system that monitors and disciplines executive officials through criminal prosecutions is problematic

litically accountable officials and which does not purport to be free of policymaking discretion. Moreover, the Independent Counsel exercises this power individually, without having to justify her decision to indict in an opinion or to a higher court, but only to an easily controlled grand jury. Finally, the Independent Counsel's duties involve an obvious political decision (whether to indict a high executive official) whereas judges (including Supreme Court Justices) are, in the great majority of cases, deciding questions that do not involve politics.

A more glaring exception to the democratic principle that policymaking officials must be electorally accountable are the heads of independent agencies. The heads of these agencies are not accountable to the President, because she cannot direct them or remove them except for cause. Yet, even these officials are subject to more political control and more checks than the Independent Counsel. First, heads of independent agencies are appointed by politically accountable officials (the President and the Senate), whereas independent counsels are selected by judges. Second, independent agencies tend to be headed by multimember commissions, which function to prevent aberrant actions, while independent counsels are always individuals. Third, independent agencies are often required to take actions after notice and comment rulemaking procedures. Independent counsels, by contrast, make the decision whether to indict on their own, subject only to the weak check of an easily influenced grand jury. Fourth, independent agency decisions are often subject to judicial review, but the Independent Counsel's decision to indict is largely unreviewable.

${ }^{18}$ This danger is compounded by the fact that the Independent Counsel has an excessive incentive to uncover wrongdoing. See supra note 16 and accompanying text (discussing the incentives independent counsels have to find wrongdoing).

${ }^{19}$ See Samuel Dash, Independent Counsel: No More, No Less a Federal Prosecutor, 86 GEO. L.J. 2077, 2094 (1998).

${ }^{20}$ See 28 U.S.C. $\$ 591$ (a), (a)(1), (c) (1994) (illustrating the Independent Counsel statute's focus upon the investigation and prosecution of high executive officials for criminal violations). 
because it both underenforces and overenforces against executive wrongdoing.

A criminal prosecution model underenforces against executive misconduct, because it ignores noncriminal misconduct that may justify dismissing an executive official, such as violations of certain civil laws and regulations. Moreover, even if an executive official does not violate a law, her actions may transgress norms of conduct important enough that their violation would justify discharging her. This principle is clearly affirmed by the Constitution's authorization for Congress to impeach executive officials for "high Crimes and Misdemeanors,", which need not constitute violations of criminal or civil law. ${ }^{22}$

Even when executive officials have committed crimes, criminal prosecutions still may be an inadequate means of holding them accountable. Criminal prosecutions require that the government prove guilt beyond a reasonable doubt in a proceeding in which the defendant enjoys many significant procedural protections. ${ }^{23}$ Thus, an executive official may be acquitted in a criminal trial even though there is strong evidence that she engaged in wrongdoing clearly warranting her dismissal from office.

In addition to underenforcing against executive misconduct, a criminal prosecution model suffers from overenforcement. In many situations, executive wrongdoing should merely result in removal. Even if an official has arguably committed a crime, the reputational damage caused by dismissal for wrongdoing often will sufficiently sanction the official and therefore the prosecutor should exercise her discretion not to indict. Because the Independent Counsel statute does not provide an alternative mechanism for disciplining executive officials, however, independent counsels will often feel compelled to indict officials who remain in office for fear that their decision not to indict will be interpreted as an exoneration.

Finally, the Independent Counsel statute places an enormous burden on executive officials and therefore on the executive branch.

21 U.S. CONST. art. II, \$4.

${ }^{22}$ See Michael J. Gerhard, The Federal Impeachment Process 103 (1996) ("The major disagreement is not over whether impeachable offenses should be strictly limited to indictable crimes, but rather over the range of nonindictable offenses on which an impeachment may be based.").

${ }^{23}$ The strict procedural requirements of criminal trials are appropriate for a process that results in imprisonment. Holding executive officials accountable, however, generally does not require that they be imprisoned; rather, it only requires that their wrongdoing be publicly disclosed and that they be dismissed from office. These lesser sanctions do not necessitate the strict procedures of criminal trials. 
The appointment of an Independent Counsel, which is usually disclosed to the public, damages the reputation of the administration as well as the official who is the subject of the investigation. The process of being investigated for a criminal violation also places the official at risk of imprisonment and therefore tends to distract her from performing her duties. Moreover, as very little evidence is necessary to trigger the appointment of an Independent Counsel, ${ }^{24}$ most administrations are likely to be subject to several independent counsel investigations. ${ }^{25}$ Because independent counsel investigations are so harmful and so easy to trigger, it is not surprising that they have become a political weapon for opponents of an administration.

In sum, the Independent Counsel statute has been a disaster. It has imposed enormous costs through an excessive number of overly intrusive investigations. Despite these costs, the statute has produced small benefits, in part because Independent Counsel investigations have often been regarded as unfair or not credible. A statute designed to promote accountability and confidence in government has instead resulted in suspicion and cynicism about government officials and independent counsels. In the end, the many problems with the Independent Counsel statute all derive from one source: the flawed vision that informs the statute-a vision that places overriding importance on the need for independent criminal investigations of executive wrongdoing and is therefore willing to sacrifice other legitimate values to that singular goal.

\section{B. Problems with Other Forms of Executive Branch Investigations}

The problems with the Independent Counsel statute have led to many proposed reforms, virtually all of which would rely on investigations by the executive branch. One type of reform would retain the concept of an independent investigator within the executive branch, but would attempt to address some of the defects of the Independent Counsel statute. ${ }^{26}$ In some plans, this independent investigator would

${ }^{24}$ See 28 U.S.C. $\$ 592(c)$ (1)(A) (1994).

${ }^{25}$ See Donald C. Smaltz, The Independent Counsel: A View from Inside, 86 GEO. L.J. 2307, 2323-24 (1998) (providing a table showing that recent administrations have each been subject to several independent counsel investigations).

${ }_{26}$ See Ken Gormley, An Original Model of the Independent Counsel Statute, $97 \mathrm{MICF}$. L. REV. 601, 606 (1998) (arguing that the Independent Counsel statute is "worth savingbut in a dramatically overhauled form designed to return the statute to its original purpose"). 
head a permanent office within the executive branch. ${ }^{27}$ A second type of reform would establish a counsel that would be subject (in theory at least) to presidential control. Some versions of this proposal would rely on the traditional system, which allows the Attorney General to appoint an ad hoc special counsel at her discretion, ${ }^{28}$ while other versions propose a permanent office to be headed by an official subject to presidential direction. ${ }^{29}$

Given how poorly the Independent Counsel statute has functioned, it is likely that most of these proposals would improve upon it. Nonetheless, all proposals that rely on executive branch investigations have serious defects. Proposals that deprive the President of the power to direct the investigations are unconstitutional and, in most cases, employ the criminal prosecution model, rely on politically unaccountable counsels, and excessively burden the executive branch. Proposals that allow the President to direct the investigations, while constitutional, have other costs. Under the ad hoc counsel version of these proposals, executive misconduct would often not be investigated, because a counsel would be appointed only for the rare scandal that causes the administration great political damage. ${ }^{30}$ Ad hoc counsels would also have an incentive to find wrongdoing, because they generally investigate one principal individual. Under the permanent official version of the proposals, the main problem is that the counsel

${ }^{27}$ See Neil Kinkopf, The Case for a Permanent Independent Counsel, WAII ST. J., Mar. 30,1999 , at A26 ("Congress should consider creating a permanent, independent office ... insulated from outside political pressures and armed with jurisdiction to investigate and prosecute allegations of wrongdoing by high-ranking officials.").

${ }^{28}$ See KATY J. HARRIGER, INDEPENDENT JUSTICE: THE FEDERAI SPECIAI PROSECUTOR IN AMERICAN POLITICS 13-39 (1992) (discussing the historical use of ad hoc special counsels).

${ }^{29}$ See TERRY EASTLAND, ETHICS, POLITICS AND THE INDEPENDENT COUNSEL: EXECUTTVE POWER, EXECUTIVE VICE 1789-1989, at 130-31 (proposing Office of Special Counsel, headed by an individual appointed by the President with the advice and consent of the Senate and removable at the sole discretion of the President); Archibald Cox \& Philip B. Heymann, After the Counsel Law, N.Y. TIMES, Mar. 10, 1999, at A19 (proposing to assign the investigation and prosecution of criminal charges against high executive officials to the Justice Department's Criminal Division); see also Thomas W. Merrill, Beyond the Independent Connsel: Evaluating the Options, 43 ST. LOUIS U. L.J. $1047,1079-80$ (proposing an office of career prosecutors, the head of which might be removable by the President).

${ }^{30}$ The President will generally not want to appoint an independent investigator who could uncover harmful information and require the administration to respond to an investigation. The President will thus only make the appointment when the political damage from not appointing an independent investigator is greater than the harm caused by appointing one. This situation will occur only when there is a significant political scandal. 
would be investigating the administration that appointed her, that can remove her, and in which she serves. Moreover, both the ad hoc and permanent counsel proposals generally employ the criminal prosecution model.

What is needed is a new approach to investigating executive branch officials-an approach that is constitutional, employs accountable officials who are independent of the President, does not rely on criminal prosecutions, and does not excessively burden the executive branch. The next Part describes such an approach.

\section{CONGRESSIONAL INVESTIGATIONS}

Instead of relying on the executive branch to police itself, Congress should investigate wrongdoing by high executive officials. Significantly, the Framers of the Constitution gave the task of investigating executive branch misconduct to the legislature. Consequently, establishing an effective institutional arrangement for congressional investigations does not, in contrast to the Independent Counsel statute, require that one bend or break the Constitution.

In this Part, I propose a system for congressional investigations of executive misconduct. First, I briefly discuss the nature and history of the congressional investigation power. Then, I describe the congressional investigation proposal in general terms. Finally, I explore changes in congressional procedures that would be needed to establish fair and effective investigations.

\section{A. Congressional Investigations: A Brief Introduction}

The Constitution authorizes Congress to investigate the executive branch for two principal purposes. First, pursuant to its impeachment power, the House of Representatives may investigate an executive official to determine whether she should be impeached. ${ }^{31}$ This power can only be exercised by the House, because the Senate's power to try impeachment cases arises only after the House has actually impeached an official. ${ }^{32}$ Second, either house may use its oversight power to collect information to help it determine whether to pass a new law. This power allows the houses to probe wrongdoing by executive officials,

${ }^{31}$ See U.S. CONST. art. I, § 2, cl. 5 ("The House of Representatives ... shall have the sole Power of Impeachment.").

${ }^{32}$ See id. $\$ 3, \mathrm{cl} .6$ ("The Senate shall have the sole Power to try all Impeachments."). 
because the information they uncover may help the houses decide whether new laws to prevent such misconduct are needed. ${ }^{33}$

The houses generally conduct investigations through committees, each of which is assisted by a staff. When a committee intends to require a witness to testify, it will often issue a subpoena. ${ }^{34}$ If the witness refuses to comply with the subpoena, the committee can then attempt to persuade the entire house to enforce it in one of various ways. ${ }^{35}$

Congressional investigations date back to George Washington's administration. The House of Representatives conducted the first significant investigation in 1792 when it inquired into a military debacle commanded by General St. Clair. ${ }^{36}$ In this century, Congress has conducted many important investigations, such as the inquiries into communist subversion during the McCarthy era, Watergate, and IranContra. ${ }^{37}$ During the Clinton presidency, Congress has examined the administration numerous times, including investigations into Whitewater, ${ }^{38}$ the Travel Office dismissals, ${ }^{39}$ the FBI files, ${ }^{40}$ campaign finance improprieties, ${ }^{41}$ Chinese espionage, ${ }^{42}$ and the Lewinsky matter. ${ }^{43}$

Like other governmental institutions, congressional investigations

${ }^{33}$ See McGrain v. Daugherty, 273 U.S. 135, 177-78 (1927) (upholding a Senate investigation into alleged wrongdoing by the Attorney General, finding that "the subject was one on which legislation could be had"); 1 RONALD D. ROTUNDA \& JOHN E. NOWAK, TREATISE ON CONSTTTUTIONAL LAW $\$ 8.1$ (3d ed. 1999) (discussing McGrain and the investigatory power of Congress).

${ }^{34}$ See JOHN C. GRABOW, CONGRESSIONAL INVESTIGATIONS: LAW AND PRACTICE $\S \S 3.1-2$ (1988) (discussing Congress's general powers of investigation and its authority to issue subpoenas).

${ }^{35}$ See infra Part II.E.1 (discussing methods of enforcing congressional subpoenas).

${ }^{36}$ See DAVID P. GURRIE, THE CONSTITUTION IN CONGRESS: THE FEDERALIST PERIOD 1789-1801, at 163-64 (1997); GRABOW, supra note 34, § 2.2; TELFORD TAYLOR, GRAND INQUEST: THE STORY OF CONGRESSIONAL INVESTIGATIONS 17-29 (1955). Currie also discusses an investigation during the First Congress of Robert Morris's conduct as Superintendent of Finance under the Confederation. See CuRRIE, supra, at 20-21.

${ }^{37}$ See GRABOW, supra note $34, \$ \S 2.4 .6$.

38 See David Maraniss, The Hearings End Much as They Began, WASH. POST, June 19, 1996, at Al.

${ }^{39}$ See Ann Devroy, Clinton May Assert Executive Privilege, WASH. POST, Sept. 8, 1995, at Al1.

${ }^{40}$ See Neil A. Lewis, Panel Chairman Demands White House Security Records, N.Y. TmES, June 25, 1996, at A15.

${ }^{41}$ See Eric Schmitt, Senators Endorse Campaign Inquiry with Wider Scope, N.Y. TIMES, Mar. 12, 1997, at Al.

${ }^{42}$ SeeJohn Bresnahan \& Jim VandeHei, Dicks Named Top Democrat on Cox Panel, GOP Leadership Plans To Give Select China Committee a $\$ 2.5$ Million Budget, Roll CALl, June 11, 1998.

${ }^{43}$ See Peter Baker \& Juliet Eilperin, Panel Votes on Party Lines for Impeachment Inquiry, WASH. POST, Oct. 6, 1998, at A1. 
have produced mixed results. At their best, these inquests have uncovered wrongdoing and led to the resignation or removal of high executive officials. For example, in the Teapot Dome investigation of the 1920s, the Senate discovered that the Secretary of the Interior had accepted money in exchange for the lease of government lands-information that eventually led to the Secretary's conviction for bribery and rescission of the leases. ${ }^{44}$ In its Watergate investigation, the Senate Select Committee on Presidential Campaign Activities, chaired by Senator Sam Ervin, examined the cover-up of the Watergate burglary. The investigation first revealed the existence of the White House tape system and disclosed serious misconduct by the President and his senior aides, which resulted in the resignation or dismissal of many of these officials, including (under threat of impeachment) President Nixon himself. ${ }^{45}$

Many investigations, however, have not been as successful. ${ }^{46}$ Indeed, I will argue that congressional investigations of executive officials have often been plagued by excessive partisanship and inadequate committee powers. Congress, however, can address these problems by changing the rules governing its investigations.

\section{B. The Proposal}

One or both houses of Congress should establish a small committee of five to seven members with the sole responsibility of investigating misconduct by high executive officials. ${ }^{47}$ The committee would have both the authority and the duty to inquire into all cases where there is evidence of wrongdoing relevant to a person's service in high governmental office. Thus, the committee would investigate not merely transgressions of criminal law, but also violations of civil laws and important norms of political propriety. ${ }^{48}$

\footnotetext{
14 See GRABOW, supra note 34, § 2.3; TAYLOR, supra note 36, at 56-57.

45 See GraBOW, supra note $34, \S 2.5$. See generally JAMES HAMILTON, THE POWER TO PROBE (1976) (providing an in-depth study of congressional investigations, especially in light of the Watergate scandal).

${ }_{46}$ For examples of recent unsuccessful congressional investigations, see sources cited infra notes 50-51.

${ }^{47}$ There are three possible ways of structuring congressional investigations: first, only one house of Congress could establish a committee; second, each house could create a separate committee; and third, the houses together could establish a single joint committee. I discuss the advantages and disadvantages of each arrangement below. See infra Part IV.A.

${ }^{48}$ In this respect, the congressional investigation proposal follows the constitutional mechanism which allows for impeachment of executive officials for actions that
} 
Upon receiving evidence of such wrongdoing, ${ }^{49}$ the committee would be required to open an investigation. The investigation, however, would be conducted differently than most other congressional investigations. First, the committee would delegate a significant portion of the investigative duties to a staff of lawyers headed by a chief counsel. Second, the committee and the staff would conduct the investigation largely behind closed doors. In this way, the committee could uncover evidence without burdening the public and innocent parties with revelations about alleged misconduct before all the evidence has been assessed and weighed.

After completing its investigation, the committee would issue a public report explaining whether it believed the official had engaged in wrongdoing and presenting the evidence supporting its conclusion. Thus, the report would provide the public with a single document allowing them to assess the strength of the case against (or for) the investigated official. In addition to issuing the report, the committee might also choose to hold hearings if it believed that its findings could be publicized more effectively in that format.

The public disclosure of wrongdoing uncovered by the committee would help the political system hold the executive branch accountable for misconduct. Communication of this information to the press and public would damage the reputations of both the official and the administration in which she served. Moreover, in the case of an official at the cabinet level or below, a report detailing serious misconduct could easily lead the administration to dismiss the official either based on genuine concern about the wrongdoing or simply to avoid political embarrassment. If the executive did not remove the official, the House of Representatives would then have the option of pursuing impeachment proceedings.

An investigation of the President, however, would probably work differently. Even if the committee uncovered evidence of serious presidential misconduct, the President would be unlikely to resign unless she were about to be, or were in the process of being, impeached. The committee's investigation, however, would still be of significant value. The investigation and report would be an important preliminary step towards the House of Representatives' determination of whether to impeach the President. Further, even if the information

need not constitute crimes. See GERFARDT, supra note 22, at 103 (discussing the possibility of impeachment for nonindictable offenses).

49 Congress can obtain evidence of wrongdoing by executive officials from numerous sources, including press reports, the executive branch, state governments, and private citizens. 
did not result in the impeachment or resignation of the President, it would still force her to incur a political price for her misconduct.

\section{Problems with Existing Congressional Investigations}

While congressional investigations have the potential to contribute significantly to the task of holding the executive branch accountable for misconduct, unfortunately the existing congressional investigative process is poorly designed to accomplish this task. Two basic problems inhibit the effectiveness of the existing process. First, congressional investigations often appear to be excessively partisan. In the last generation, the majority party in Congress has generally differed from the party in control of the White House. In this situation, the majority party is often criticized for overly aggressive investigations of minor matters and improbable accusations, whereas the minority party is viewed as resisting inquiries of even the most serious and credible charges. ${ }^{50}$ In addition, the majority party often portrays the results of the investigation in the most damaging terms to the administration, while the minority party frequently minimizes the significance of those results.

${ }^{50}$ See Guy Gugliotta \& Susan Schmidt, Congressional Investigations: More Partisan, Less Powerful, WASH. POST, Nov. 20, 1997, at A23; Saundra Torry, Up on the Candidate's Stump, and Taking Shots, WASH. POST, Oct. 14, 1996, at H7.

See Francis X. Clines, Campaign Panel To End Hearings on Fund Raising, N.Y. TIMES, Nov. 1, 1997, at A1; Ed Henry, "Vindication" Is Hope for Thompson in His Report, Roll CAIL, Nov. 17, 1997, at 1; Amy Keller, Burton Releases Interim Report, Vows To Continue Probe, ROLL CAIL, Oct. 12, 1998, at 15 [hereinafter Keller, Interim Report]; Amy Keller, Waxman, House Democrats Attack GOP Partisanship, ROLI CAII, Oct. 8, 1998, at 27 [hereinafter Keller, GOP Partisanship].

A recent example of an investigation marred by partisan disputes was the inquiry into campaign finance violations conducted by Congressman Dan Burton's Government Reform and Oversight Committee. The Democrats repeatedly charged that Chairman Burton conducted an unfair and overreaching investigation. See Jennifer Bradley, Staff Exodus Jolts Burton Probe of 1996 Fundraising, ROLL CALL, July 3, 1997, at 1; Keller, GOP Partisanship, supra; Keller, Interim Report, supra. The Republicans, in turn, maintained that the Democrats had obstructed the investigation and had refused to support the conferral of immunity for several witnesses without sufficient reason. See Amy Keller, Four Witnesses Get Immunity from Burton Panel, ROLI CALI, June 25, 1998, at 12; George Lardner Jr., Burton Panel Sputters as Immunity Vote Fails, WASH. POST, May 14, 1998, at Al4.

Similar problems arose in the investigation of campaign finance improprieties chaired by Senator Fred Thompson. The Democrats maintained that the Republicans sought to investigate only Democratic Party misconduct and criticized the inquiry as unfair. See David Jackson, Clinton Fund-Raising Inquiry Hits Snags, DALLAS MORNING NEWS, June 12, 1997, at 1A; Robert Schlesinger, Thompson Panel Dems Allege Obstruction of Justice, THE HIIL, Feb. 18, 1998, at 3. The Republicans responded that the Demo- 
The most serious consequence of this excessive partisanship has been to reduce the credibility of the information and findings produced by congressional committees. Because the majority party often exaggerates the results of its investigations and the minority party frequently criticizes the majority's investigation, maintaining that it revealed little, the public and the press tend to view the information produced by the investigation with skepticism. Congressional investigations would be far more effective if they were conducted by committees consisting of members who had reputations for integrity and who did not often vote on party lines. Indeed, some of the most effective investigations have involved committees that have suppressed partisan disagreements and compromised. ${ }^{52}$ For example, the Cox Committee's investigation into Chinese espionage has been lauded for its avoidance of partisanship, and its report has consequently been received positively in the press. ${ }^{53}$

The second problem with congressional investigations is that committees have often lacked the power to conduct effective investigations. First, congressional committees have sometimes had difficulty enforcing their subpoenas, especially against executive officials. ${ }^{54}$ There are several existing methods for enforcing congressional sub-

crats had impeded the investigation by insisting that it terminate on a specific date and thereby allowing witnesses to pursue a strategy of delay. See Helen Dewar, Senate Talks on Campaign Finance Probe Grow Contentious, WASH. POST, Feb. 8, 1997, at A4; Thompson Wants More Time for Probe, ARIZ. REPUBLIC, Oct. 29, 1997, at A6.

52 The Ervin Committee that investigated the Watergate cover-up, despite political differences between the members, was often able to reach agreement on fundamental matters. See, e.g., GraBow, supra note 34, $\$ 2.5[\mathrm{c}$ ] (noting that the Ervin Committee unanimously rejected the request of the Special Prosecutor to postpone the hearings). Even the Burton committee became more effective once it sought to compromise. See A.B. Stoddard, Dems Agree to Immunity Grant in Exchange for Two Changes in Rules, THE HIIL, June 24, 1998, at 1; see also E.J. Dionne, Jr., "A Quiet Civil War, "WASH. POST, Mar. 29, 1994, at A19 (noting that the "reputation for bipartisanship" of Chairman Jim Leach gave his charges against President Clinton concerning Whitewater "added credibility").

${ }^{53}$ See Juliet Eilperin, Hill Unites in Exposing Chinese Espionage, WASH. PoST, May 25, 1999, at A4 (praising Congressman Christopher Cox's bipartisan approach in reaching agreement on damage caused to U.S. security by China's alleged theft of nuclear secrets); John Mintz, China Aid Hurt U.S. Security, Panel Says, WASH. POST, Dec. 31, 1998, at Al (remarking that the special panel chaired by Cox was a "rare show of bipartisanship").

${ }^{54}$ See John Bresnahan, Young Threatens Contempt, Roll CALL, July 26, 1999, at 1; Amy Keller \& Ed Henry, Early Exit, Subpoena Problems Could Hurt Senate Investigation, Roll CALL, Sept. 1, 1997, at 1; Amy Keller, Groups Join Together To Fight Senate Subpoenas, Roll CALL, Sept. 4, 1997, at 26; Keller, Interim Report, supra note 51; Gil Klein, Thompson Warns Clinton: Stop Stalling That Suggests Cover Up, RICHMOND TIMESDISPATCH, Oct. 8, 1997, at AI; Edward Walsh, Another Bump in Burton Panel's Road, WASH. POST, May 13, 1998, at A4. 
poenas, but each has serious problems. ${ }^{55}$ Second, congressional committees have often lacked the power to authorize their staffs to question witnesses who are under oath. ${ }^{56}$ If the staff cannot ask these questions, then members of the house must do so. Requiring that members question the witnesses, however, may impede the investigations because these legislators have many other responsibilities and may not be able to devote the time necessary to the task. ${ }^{57}$

Interestingly, the two basic problems with existing congressional investigations-excessive partisanship and the lack of adequate power for the committees-may be related. In part, Congress and the President may be unwilling to confer significant authority on committees because they fear that partisans may abuse this authority. Thus, a new procedure is needed that will reduce the degree of partisanship on investigative committees and allow these committees to be given more power.

\section{Appointing the Committee}

Under existing congressional rules, each party appoints the committee members from its own party. ${ }^{58}$ Thus, the Republicans select the Republican members of committees and the Democrats choose the Democratic members. Unfortunately, this appointment method has often produced investigative committees that are prone to excessive political partisanship. Congressional investigations of executive wrongdoing would be more effective if investigative committees were less partisan. Surprisingly, there is a practical method for selecting

${ }^{55}$ See infra Part II.E.1 (discussing the three existing methods for enforcing congressional subpoenas and the problems with these methods); see also infra note 71 and accompanying text (discussing a famous example of the executive branch's refusal to criminally prosecute an agency head for contempt of Congress).

${ }^{56}$ See JAY R. SHAMPANSKY, LIBRARY OF CONGRESS, PUB. No. 91-679A, CONGRESSIONAL RESEARCH SERVICE REPORI FOR CONGRESS: STAFF DEPOSITIONS IN CONGRESSIONAL INVESTIGATIONS (1991).

${ }^{57}$ Members may also be less skilled at questioning than the staff would be. By contrast, committees that can employ their staff to question witnesses who are under oath have proven effective. For example, the Iran-Contra inquiry, despite its political problems, used staff depositions to great effect in investigating a large number of witnesses. See GrABOW, supra note 34, § 2.6[c], [i]. Indeed, Grabow suggests that the reliance on staff depositions, rather than closed hearings attended by many members and staff, may have helped to limit the number of leaks of confidential information to the media. See id. at 56 n.41.

${ }^{58}$ See CONGRESSIONAL QUARTERLY INC., How CONGRESS WORRS 121, 146-47 (3d ed. 1998) [hereinafter HOw CONGRESS WORRS] (describing how the two houses select members for committees). 
such a committee. Each house should change its rules to allow the Republicans to choose the Democratic members of the investigative committee and the Democrats to select the Republican members. ${ }^{59}$

This interparty appointment method would have two principal effects. First, it would provide each party with an incentive to choose members of the other party who were political moderates. For example, Republicans would prefer the most centrist Democrats, whose political views are generally the closest to those of Republicans. Second, each party would have an incentive to select persons from the other party who have reputations for integrity-that is, for acting based on the evidence rather than on party solidarity or political considerations. Democrats, for instance, would obviously prefer those Republicans who would judge a Democratic administration based on the facts rather than on the opportunity to make political points. Although each party would desire members from the other party who were both political moderates and had integrity, they would often be forced to compromise on one characteristic to obtain someone who possessed the other. Political moderates do not necessarily have the most integrity. Moderates can be quite political, whereas legislators with more extreme political views are often principled people with tremendous integrity. Each party would thus choose members from the other party who scored the most on a scale that measured both characteristics.

Significantly, this interparty appointment process would select for the committee exactly those members most desirable from a public policy perspective. First, the committee should be composed of political moderates. This is not because political moderation is preferable to radicalism, but because the committee will be more effective if its members have similar views. The committee will then often be able to act by consensus, and when disagreements do occur, they will tend to be small. Second, the committee should also be filled with members who act based on the evidence rather than on political considerations. Investigations of executive wrongdoing should depend on the behavior of the officials being investigated, not on their political affiliation.

A committee selected by the interparty appointment process would therefore have many desirable features. Because the committee would be composed of members who have integrity and often act

${ }^{59}$ Under this appointment method, a member selected for the investigative committee by the other party would be required to serve, subject to the exceptions discussed below. See infra text preceding note 61. 
by consensus, the committee's reports would tend to have great influence with the press and the public. Moreover, since it would be composed of political moderates, the committee would be unlikely to take actions that Congress and the President would regard as extreme and unwarranted. As a result, Congress and the President might be willing to provide it with the significant powers it would need in order to be effective. ${ }^{60}$

It might be argued, however, that the interparty appointment method would work differently in practice than in theory. Although in theory the parties would select political moderates who have integrity, in practice they might pursue other strategies. For example, one party might choose members of the other party, such as the party leaders or committee chairs, who had other duties and would thus be distracted or burdened by serving on the investigatory committee. Alternatively, the party that holds the White House might select members from the other party who they believed were prone to incompetent and embarrassing actions, so that their actions and those of the committee could be ridiculed and dismissed. Finally, the party that holds the White House might select members from the other party who have ethical or other problems of their own to make it embarrassing or difficult for them to investigate the administration.

These concerns about the appointment process, however, could be addressed. First, the problem of a party selecting party leaders or committee chairs could be eliminated by allowing these members to refuse to serve. Second, the concern of a party selecting members who may be ridiculed or who have embarrassing problems could be addressed by allowing each party to veto a limited number of appointments made by the other party. For example, if the Senate investigatory committee were to consist of four Democrats and three Republicans, the Republicans might be required to select eight Democrats for the committee, with the Democrats permitted to choose the four members that they preferred. The Republicans could not then force one or two problematic Democrats on to the committee. Another check on such strategic behavior is that the party selecting the embarrassing members would pay a price for doing so. It is true that under existing procedures, the minority party has sometimes believed that ridiculing problematic committee chairs was a good strategy. ${ }^{61} \quad$ But under existing procedures the majority party selects

${ }^{60}$ See infra Part II.E (discussing the additional powers the committee would need to be effective).

${ }^{61}$ See Gugliotta \& Schmidt, supra note 50. 
committee chairs, whereas under the interparty appointment procedure, the minority party would do so. Thus, the minority party would be criticized for attempting to manipulate the system and for selecting inappropriate candidates. The minority party would also find it difficult to criticize members whom it chose for the committee.

One final issue concerns the political composition of the committee. In my view, the proportion of members from each party on the investigative committee should, as is true generally of committees, reflect the proportion of members from each party in the parent house. Thus, if one party had a slight majority in the parent house, it would also have a slight majority on the committee. It might be argued, however, that the premises underlying the interparty appointment process suggest that the investigatory committee should have an equal number of members from each party. In this way, the committee's decisions would not reflect political considerations, but instead the merits of the investigation. This argument, however, is mistaken because it assumes that it is possible to eliminate politics from the investigation of high executive branch officials. That was the premise of the Independent Counsel statute, but experience has shown that to be false. ${ }^{62}$ When it comes to the high stakes politics of investigating a President or cabinet official, political considerations can be reduced but not eliminated. If the minority party enjoyed equal representation on the committee it could abuse this power by, for example, resisting investigations or subpoenas of executive officials from its party. Thus, equal representation on the committee would not eliminate politics, but would simply rearrange the constellation of political forces in the investigative process. ${ }^{63}$

Even if one could eliminate the role of politics, it is not clear that doing so would be desirable. Politics adds a dimension of responsibility. When members of the majority party make a decision based on the party's political views and interests, voters can hold the party responsible at the polls. This responsibility allows more general principles and interests to be reflected and judged in the political process. Well-functioning institutions often do not eliminate political forces, but merely prevent such forces from having an excessive influence.

${ }^{62}$ See sources cited supra note 14.

${ }^{63}$ The majority party in Congress is also unlikely to adopt a system with equal representation. Even with unequal representation, an interparty appointment process arguably reduces the power of the majority party. Although I argue below that the benefits to the majority party from such an appointment process might lead that party to support it, see infra Part IV.C, equal representation would so significantly reduce the power of the majority party that it would be very unlikely to adopt it. 
There is a strong analogy here between the interparty appointment process and the classical American justifications for a large national republic and the system of checks and balances. In The Federatist Papers, James Madison discussed two serious problems for government: factions in the political process and the desire of politicians for power. Significantly, Madison did not seek to solve these problems by attempting to eliminate their causes directly, but instead by modifying the structure of government to reduce their harmful effects. Thus, in The Federalist No. 10, Madison did not try to eradicate factions, but rather tried to mitigate their malevolent consequences by forming a large republic. ${ }^{64}$ Similarly, in The Federalist No. 51, Madison does not attempt to extinguish the desire for power, but instead to moderate its dangerous results by making ambition counteract ambition with checks and balances. ${ }^{65}$ The interparty appointment process likewise does not attempt to eliminate each party's partisan preferences. Instead, it attempts to lessen their harmful effects by altering the method of appointment so that the partisan desires of each party lead it to select the most appropriate members of the opposing party for the committee.

\section{E. Additional Powers of the Committee}

In order to conduct effective investigations, the investigative committee would also need significant powers. The committee would, of course, require the ordinary powers possessed by committees, such as the power to hire a staff, to issue subpoenas, to write reports, and to grant immunity by a two-thirds vote of the members. ${ }^{66}$

The investigative committee, however, would also need several powers that existing committees do not generally enjoy. First, the committee would require a better method of enforcing subpoenas against executive officials than committees presently possess. Second, the committee would need the power to authorize its staff to conduct significant parts of the investigation, including questioning witnesses who are under oath. Finally, the committee would need access to additional funds for investigations without having to secure approval from the parent house. In each of these cases, adequate authority

64 THE FEDERALIST No. 10 (James Madison).

${ }^{65}$ THE FEDERALIST NO. 51 (James Madison).

${ }^{66}$ See 18 U.S.C. $\$ 6005$ (1994 \& Supp. IV 1998) (conferring power on committees to grant immunity); GRABOW, supra note $34, \S \S 3.1-3.6$ (describing the tools of inquiry available to Congress in conducting investigations). 
could be provided to the committee.

\section{The Power To Enforce Subpoenas}

The investigative committee must have the power to effectively enforce its subpoenas. Without this authority, the committee's requests for testimony and documents could be ignored without legal consequences. There are currently three ways to enforce legislative subpoenas, but none of them is adequate for investigations of executive misconduct.

First, each house of Congress has the inherent authority to arrest and try someone for contempt if she fails to comply with a lawful subpoena. A contemptuous witness can be imprisoned, but only through the duration of the pending session of Congress. ${ }^{67}$ The main problem with this procedure is that it requires a house to hold a timeconsuming trial. As a result, Congress has not invoked its inherent power since the 1930s, relying instead on other methods.

Second, contemptuous witnesses may be prosecuted for criminal contempt. Congress has enacted a statute making it a misdemeanor for a witness to willfully refuse to answer a question. 68 There are, however, problems with using this procedure to require testimony from executive branch officials. First, the procedures require a U.S. Attorney to prosecute the criminal contempt, but U.S. Attorneys serve at the pleasure of the President. ${ }^{69}$ Thus, they may be reluctant to prosecute contempt charges against officials in the administration in which they serve. ${ }^{70}$ Second, the criminal character of the contempt might also give the U.S. Attorney an excuse to forego prosecution. Because it is often difficult to prevail in a criminal prosecution, the U.S. Attorney could argue that it is not worth devoting resources to prosecution. Because the contempt carries a criminal sanction, the U.S. Attorney might also argue that prosecuting the case would be excessive, especially if the official's refusal to answer was based on a presidential as-

${ }^{67}$ See Anderson v. Dunn, 19 U.S. (6 Wheat) 204, 231 (1821); GRABOW, supra note $34, \S 3.4[\mathrm{a}]$ (describing Congress's self-help contempt power).

See 2 U.S.C. $\$ 192$ (1994).

${ }^{69}$ See 28 U.S.C. $\$ 541$ (1994).

${ }^{70}$ U.S. Attorneys probably are more likely to bring these actions than to investigate executive wrongdoing from scratch. When the U.S. Attorney receives a referral for criminal contempt, it is hard for her to claim there is no factual basis for not prosecuting, because the facts have already been developed. By contrast, if a U.S. Attorney were asked to investigate an executive official, she could fail to develop the facts and claim there was little evidence of wrongdoing. Nonetheless, U.S. Attorneys still cannot be relied upon to prosecute the criminal contempt case with full vigor. 
sertion of executive privilege. The difficulties of using a prosecution for criminal contempt to enforce subpoenas are illustrated by the case of Ann Gorsuch Burford, Administrator of the Environmental Protection Agency during the Reagan Administration. After the Democratcontrolled House of Representatives found her in criminal contempt for refusing to provide documents which had been the subject of an executive privilege claim, the U.S. Attorney refused to prosecute. ${ }^{71}$

These problems have led Congress to adopt a third method for enforcing subpoenas. In 1978, Congress passed statutory authority allowing the Senate to bring civil actions to enforce its subpoenas in federal court. Under this statute, the entire Senate must authorize the action, which will normally be brought by the Senate legal counsel. $^{72}$ If the federal court determines that the subpoena was legal and no defenses were available against it, the court must enforce the subpoena without exercising any discretion as to whether it was appropriate for the Senate to issue the subpoena. ${ }^{73}$ If the witness refuses to obey the court's order, then the court would hold her in contempt until she complies.

This civil enforcement scheme avoids many of the problems of the criminal contempt mechanism. Because it provides a civil remedy, the Senate need not prove its case beyond a reasonable doubt as it would in a criminal trial. The Senate can also bring the action itself rather than having to rely on the executive branch.

Although this civil enforcement scheme has significantly improved the legislature's ability to enforce committee subpoenas, several features of existing law would need to change in order to provide the investigative committee with adequate authority. First, because only the Senate presently possesses civil enforcement authority, legislation would be required to confer it on the House as well. Second, the Senate's authority does not allow a committee to independently enforce the subpoena, but instead requires the entire Senate to approve the

${ }^{71}$ See GRABOW, supra note 34, § 3.4[b] [5] (describing the inability of the House of Representatives to secure Gorsuch Burford's contempt prosecution in 1982). See generally Todd D. Peterson, Prosecuting Executive Branch Officials for Contempt of Congress, 66 N.Y.U. L. REV. 563, 625-31 (1991) (discussing criminal sanctions for contempt of Congress in light of the incident involving Gorsuch Burford).

${ }^{72}$ See 2 U.S.C. § $288 \mathrm{~d}(\mathrm{a})$ (1994); 28 U.S.C. § 1365(a)-(b) (1994); see also James Hamilton \& John C. Grabow, A Legislative Proposal for Resolving Executive Privilege Disputes Precipitated by Congressional Subpoenas, 21 HARV. J. ON LEGIS. 145, 150 (1984).

${ }^{73}$ See In re Application of the U.S. Senate Permanent Subcomm. on Investigations (Cammisano), 655 F.2d 1232, 1238 (D.C. Cir. 1981); Senate Select Comm. on Ethics v. Packwood, 845 F. Supp. 17, 20-21 (D.D.C. 1994). 
action. ${ }^{74}$ This would be a drawback because the investigative committee would be specially appointed so that it would behave differently than the parent house. If the committee must secure the approval of the entire house, the house might place unreasonable conditions on its approval that would interfere with the investigation. Thus, the committee should have independent authority to enforce its subpoena. ${ }^{75}$ Finally, the Senate's authority to enforce subpoenas does not extend to subpoenas against executive officials. ${ }^{76}$ Clearly, in order to use the authority to investigate executive misconduct, it would need to cover executive officials. This would allow the committee to question the target of the investigation and her co-workers.

To ensure that the committee has adequate authority, Congress should therefore pass a law allowing a specially appointed investigative committee from either house to enforce its subpoenas against executive officials. Such a law might engender two possible objections. First, some commentators have argued that Congress should not be allowed to bring civil suits against executive officials to enforce subpoenas. They contend that interbranch disputes over information requests should be resolved through informal negotiation between the branches rather than through adjudication by the courts. ${ }^{77}$ Under this view, negotiation will result in a resolution that is more sensitive to the needs of the branches while appropriately limiting the power of the courts in an interbranch dispute. If we assume for purposes of argument that the adjudication of interbranch information disputes is undesirable, then allowing Congress to bring civil enforcement suits against executive officials would be a cost of the congressional investigation proposal. Nonetheless, there is a way to minimize these costs. The authority to enforce subpoenas against executive officials should be reserved for the specially appointed committee that only has the power to investigate high executive officials for wrongdoing. This limitation would prevent Congress from using the authority merely for

${ }^{74}$ See GRABOW, supra note 34, § 3.4[c] n.86.

${ }^{75}$ Clearly, there is no constitutional problem with transferring the power to seek judicial enforcement of subpoenas from the entire house to the committee. Individual committees can exercise many significant powers, including the power to issue subpoenas and the power to grant immunity to a witness. See id. $\$ \S 3.2[\mathrm{a}]-[\mathrm{c}], 3.6$. These powers are no less significant than the power to seek judicial enforcement of subpoenas.

76 See 28 U.S.C. § 1365(a) (Supp. V 1999).

77 See Neal Devins, Congressional-Executive Information Access Disputes: A Modest Proposal-Do Nothing, 48 ADMIN. L. REV. 109, 114-16 (1996); Peterson, supra note 71, at 625-31. 
oversight purposes and would only bestow the authority upon a committee appointed by a method designed to prevent it from being controlled by partisans. Thus, the authority could be used only in limited circumstances-when a moderate committee concluded it was necessary for investigating executive branch wrongdoing-and therefore when the benefits were likely to exceed the costs.

The second objection questions the constitutionality of congressional lawsuits to enforce subpoenas. It might be argued that bringing a lawsuit to enforce a government subpoena is executive power and therefore cannot be exercised by the legislature. ${ }^{78}$ The power of a congressional committee to seek judicial enforcement of a subpoena, however, is also legislative power. Such power, I will argue, is part of the legislative authority of the two houses over impeachments and oversight. $^{79}$

In examining the constitutionality of a committee's power to seek judicial enforcement of subpoenas, it is essential to view this power in conjunction with the traditional power of a legislative house to punish contempts. Because these two powers are similar, our analysis of one will affect how we analyze the other.

The traditional power of the houses to punish contempts allows each house to imprison individuals who engaged in contemptuous behavior, such as refusing to comply with a subpoena or other binding requests for testimony. ${ }^{80}$ In exercising this power, the house would adjudicate whether the individual had committed the contempt. If the individual were found guilty, she was imprisoned in the Capitol itself or in the Washington, D.C. jail.

The Supreme Court held this inherent power to punish contempts to be constitutional in a series of cases beginning with Anderson v. Dunn in $1821 .^{81}$ These cases provide two strong reasons for concluding that the Constitution permits legislative houses to imprison

${ }^{78}$ If a committee lawsuit to enforce a legislative subpoena were executive power, the existing Senate authority, which does not extend to executive officials, would also be unconstitutional. The question of whether the enforcement of a subpoena is executive power does not turn on the object of its enforcement.

${ }^{79}$ See supra notes 31-33 and accompanying text (discussing how Congress's investigative authority is derived from its impeachment and oversight powers).

${ }^{80}$ See supra notes 67-68 and accompanying text.

8119 U.S. (6 Wheat.) 204 (1821); Jurney v. MacCracken, 294 U.S. 125, 149-52 (1935); McGrain v. Daugherty, 273 U.S. 135, 174 (1927) ("We are of the opinion that the power of inquiry-with the process to enforce it-is an essential and appropriate auxiliary to the legislative functions."); Marshall v. Gordon, 243 U.S. 521, 542-46 (1917) (confirming an implied power of Congress to punish for contempt). 
witnesses who do not comply with subpoenas. ${ }^{82}$ First, traditionally Anglo-American legislatures, including the House of Commons, the colonial legislatures, many of the state houses prior to and after the ratification of the Constitution, and early Congresses had the power to punish contempts. ${ }^{83}$ Moreover, in several of the state constitutions, this power was not conferred through an explicit provision. ${ }^{84}$ Instead, the power was deemed an inherent attribute of legislative houses and was apparently implied from the provision establishing the house. This history suggests that the Framers and Ratifiers of the U.S. Constitution believed that the legislative houses possessed this power without any explicit provision conferring it.

Second, constitutional structure and purpose support an interpretation that would allow the houses to punish individuals who violate their subpoenas. Without this power, the houses would have to rely on executive branch prosecutions for enforcement of their subpoenas. ${ }^{85}$ This reliance, however, would render the impeachment and

${ }^{82}$ Traditionally, legislatures could punish actions other than failing to comply with a lawful subpoena as contempts. Other examples of contempts included attempts to bribe members, libels and slanders of members, and interferences with legislative privileges. See C.S. Potts, Power of Legislative Bodies To Punish for Contempt, 74 U. PA. L. REv. $691,692-99,707-12,715-18,719-25$ (1926). In this Section, I only defend Congress's power to punish contempts that involve the violation of lawful subpoenas. Other contempts may raise additional issues (such as whether they are consistent with other constitutional provisions like the First Amendment). Cf. Marshall v. Gordon, 243 U.S. 521, 542 (1917) (reading the contempt power narrowly to forbid the House from punishing an individual who slandered the House but presented no immediate obstruction to the legislative process).

${ }_{83}$ See James M. Landis, Constitutional Limitations on the Congressional Power of Investigation, 40 HARV. L. REv. 153, 165-68 (1926); Potts, supra note 82, at 692-99, 708-12, 71518, 719-25. Although many of the examples relied upon by these commentators to show that the legislative houses had the power to punish contempts involved the failure to provide evidence to a committee, some examples involved other types of contempts as well. See supra note 82 (describing other types of contempts). While I am here concerned with a house's power to punish individuals who fail to comply with subpoenas, evidence of punishment for other contempts supports a house's authority to punish for subpoena violations.

${ }_{85}^{84}$ See Potts, supra note 82 , at 715.

${ }^{85}$ My conclusion that the individual houses have the power to seek judicial enforcement of their subpoenas might seem inconsistent with the claim that if the houses did not have the power to punish contempts, they would have to rely on the executive branch to enforce their subpoenas. This is not so. My argument that the houses have the power to seek judicial enforcement relies on the power of the houses to punish contempts. Thus, if the houses did not have the power to punish contempts, they would not have power to seek judicial enforcement of their subpoenas either.

One could, of course, imagine a different argument for the power to seek judicial enforcement that does not rely on the power to punish contempts. If one accepted this argument, then one could not also claim that the power to prosecute contempts 
oversight powers far less effective because the executive branch might be reluctant to aid congressional investigations of itself. The Framers placed great importance on the system of checks and balances. It is unlikely that they would have created a check on the executive that required the executive's active cooperation for its enforcement. Indeed, the Framers designed the impeachment power to be used against a tyrannical president unwilling to assist in her own removal. ${ }^{86}$ Thus, strong evidence would be needed before one concluded that the Framers deprived Congress of the power to enforce legislative subpoenas.

Once one determines that the houses possess the power to punish contempts, it is a short step to concluding that they also have the authority to seek judicial enforcement of their subpoenas. This is because the power to seek judicial enforcement is merely one component of the power to punish contempts. The power to punish contempts includes the power to decide to prosecute someone for committing a contempt; to adjudicate whether she committed the contempt; and then to imprison her. By contrast, the power to seek judicial enforcement of a subpoena is no broader than one of these powers alone: the power to prosecute. ${ }^{87}$ The remainder of Congress's power to punish contempts is either placed in the other branches (with adjudications in the courts and imprisonment by the executive) or not exercised at all (because Congress does not attempt to impose a criminal sanction for failure to obey a subpoena). Thus, if Congress's power to punish for contempts is legislative power, then certainly its exercise of a portion of this power for a similar purpose should also be deemed legislative power.

In addition to being narrower than the power to punish contempts, the power to seek judicial enforcement of subpoenas also better comports with principles embedded in the Constitution and held by the Framers. First, the power to seek judicial enforcement respects separation of powers and due process principles far more than does the power to punish contempts. When a house exercises the power to punish contempts, it combines two otherwise separate powers: prose-

helped prevent Congress from relying exclusively on the executive branch for enforcement.

${ }^{86}$ See generally THE FEDERAIIST NOS. 65, 77 (Alexander Hamilton).

${ }^{87}$ Actually, the power to seek judicial enforcement is narrower than the power to prosecute a contempt. When Congress pursues judicial enforcement, it enforces the subpoena by asking a court to order the subject of the subpoena to comply. When Congress prosecutes a contempt, it enforces the subpoena by imprisoning the individual. 
cution and adjudication. It also conflicts with the fundamental due process principle, embraced by the Framers, that no entity, including Congress, should judge its own case. ${ }^{88}$ Second, the power to seek judicial enforcement better conforms to constitutional checks and balances. Although this power allows the legislative houses to check the executive by enforcing subpoenas against executive officials, it is less likely to create an unbalanced constitution where Congress can imprison executive officials solely on its own determination that they have violated legislative subpoenas. Third, the power to seek judicial enforcement uses a more modest sanction-a court order rather than imprisonment-to enforce subpoenas than does the power to punish contempts. Consequently, the power to seek judicial enforcement furthers the Framers' preferences for less intrusive government authority. ${ }^{89}$ It is also less likely to provoke executive retaliation and degenerate into the type of full-blown factional conflict that the Framers so feared. ${ }^{90}$

Thus, I conclude that a house's power to seek judicial enforcement of a legislative subpoena is legislative power and therefore constitutional. $^{\text {9I }}$ This power is narrower than the power to punish con-

88 See THE FEDERAIIST No. 10, at 79 (James Madison) (Clinton Rossiter ed., 1961). Due process concerns are especially heightened because contempts are punishable by imprisonment.

${ }^{89}$ Another factor supporting the constitutionality of the legislative power to seek judicial enforcement of subpoenas is that it does not involve criminal prosecution. If the houses were attempting to bring criminal prosecutions in court, this would be extremely problematic. Criminal prosecution in the courts is an inherently executive function. By contrast, the authority to seek judicial enforcement of a subpoena is regularly exercised by private parties in lawsuits. See FED. R. Crv. P. 45. Although the power to punish contempts does allow the houses to imprison individuals, that power is historically distinct from the power to criminally prosecute in federal court and incorporates additional limits, such as the prohibition on imprisoning an individual beyond the duration of the pending session. See Anderson v. Dunn, 19 U.S. ( 6 Wheat.) 204, 231 (1821).

${ }_{90}$ On the Framers' fear of factions, see, for example, THE FEDERAIIST NO. 10 (James Madison).

${ }^{91}$ It might be thought that even if the power to seek judicial enforcement of a subpoena is legislative power, this authority, like other forms of legislative power, must be exercised in accordance with bicameralism and presentment. See INS v. Chadha, 462 U.S. 919, 956-59 (1983) (finding the one-house legislative veto unconstitutional as a violation of bicameralism and presentment). The Constitution, however, clearly contemplates that the individual houses can exercise certain legislative powers, two of which are impeachment and oversight. See U.S. CONST. art. I, $\$ 2, \mathrm{cl} .5$ (providing the House with the sole power to impeach); id. $\S 3$, cl. 6 (providing the Senate with the sole power to try impeachments); McGrain v. Daugherty, 273 U.S. 135, 137 (1927) ("Each House of Congress has power to conduct an investigation in aid of its legislative functions."). Thus, individual houses may enforce subpoenas in furtherance of these 
tempts and is more in accord with principles embedded in the Constitution. ${ }^{92}$

\section{The Authority To Empower the Staff To Conduct Investigations}

In order to conduct effective investigations, the proposed investigatory committee would also need to be able to delegate more authority to its staff than does the ordinary congressional committee. Delegation to the staff of a significant part of the investigative work would serve several purposes. It would avoid placing significant burdens on the committee members, who have many other legislative responsibilities. Moreover, because committee members would not be burdened by investigations, the committee could authorize as many investigations as necessary and pursue them as intensively as warranted. The committee could also conduct more effective investigations because the staff would have expertise and experience that many members lack. ${ }^{93}$

Although it would do a significant part of the investigating, the staff would remain subordinate to the committee members. Important policy decisions would always be made by the committee as a whole. In particular, only the committee would open investigations, grant immunity, issue subpoenas, and rule on objections raised by

powers.

${ }^{92}$ Some readers might be skeptical about the existence of Congress's power to punish contempts relating to its oversight power, because the oversight power is not explicitly mentioned in the Constitution. In this Essay, I have assumed, based on Supreme Court precedent, that the oversight power is constitutional. But even if Congress did not possess the oversight power, one could persuasively argue that the houses would still have the power to punish contempts when acting under their constitutionally explicit impeachment powers. Indeed, the Supreme Court's decision in Kilboum $v$. Thompson, 103 U.S. 168 (1881), although extremely skeptical about a general legislative power to punish contempts, admitted that the houses had this power when exercising their impeachment authority.

Furthermore, even if one believed there was no congressional power to punish contempts, including those relating to impeachments, this would not necessarily mean that the houses lacked the power to seek judicial enforcement of subpoenas. If the houses had no power to punish contempts, they would need the power to seek judicial enforcement of subpoenas all the more, or else they would be forced to rely on the executive branch's willingness to enforce subpoenas against itself.

${ }^{93}$ If the staff is to exercise significant authority, it should be headed by someone who is both competent and trustworthy. The head of staff or chief counsel would supervise the day-to-day operations of the investigations and report to the committee members. To ensure that the person chosen for chief counsel had the confidence of the entire committee, she should probably be appointed by a supermajority vote of the committee. To ensure that the chief counsel is accountable to the committee, however, she should be removable by a simple majority. 
witnesses. In this way, only electorally accountable officials would make the important policy decisions.

The most important power that the committee would need to delegate is the authority to question witnesses who are under oath. Without this authority, committee members would have the burdensome task of posing all the questions. The problem, however, is that existing legislative rules often forbid committees from delegating this power to their staffs. Instead, committees must first obtain the approval of the parent house before granting questioning authority to staff members. ${ }^{94}$ Under this arrangement, the investigative committee might have to regularly employ its political capital to secure the authority it would need. Moreover, the parent house might attempt to use its power to withhold approval to impose conditions on the committee's investigations.

There are good reasons why the parent houses often require committees to receive approval before allowing their staffs to question witnesses who are under oath. Certain committees have used their powers very aggressively. Requiring the committee members to ask the questions themselves limits the committee's ability to use and abuse its powers. Congress, however, should be far less hesitant to delegate this authority to the investigating committee, which is specially appointed and therefore unlikely to abuse its authority. ${ }^{95}$

One question is whether it is constitutional for the staff to question witnesses who are under oath. Congress appears to believe it is constitutional, because both houses sometimes allow committees to delegate this authority to their staffs. ${ }^{96}$ The Constitution, however, clearly places some limits on how much authority legislative staff can exercise, since it vests legislative power in the two houses of Congress and states that each house consists of its members. ${ }^{97}$ Although the

${ }^{94}$ See GRABOW, supra note $34, \S 3.3$ (discussing the use of staff depositions to obtain sworn witness testimony); MORTON ROSENBERG, LIBRARY OF CONGRESS, PUB. NO. 95464A, CONGRESSIONAI RESEARCH SERVICE REPORT FOR CONGRESS: INVESTIGATING OVERSIGHT: AN INTRODUCTION TO THE LAW, PRAGTICE AND Procedure OF CONGRESSIONAL INQUIRY (1995).

${ }_{95}$ In addition to allowing the investigative committee to delegate the power to question witnesses to its staff, Congress would also need to adjust related statutessuch as those governing criminal contempt, perjury, obstruction of justice, and other similar matters-to clarify that they apply when the staff questions witnesses who are under oath. See SHAMPANSKY, supra note 56, at 8-15 (discussing the application of perjury and contempt statutes to false statements made in response to staff questions).

${ }_{96}$ See supra note 94 (citing sources that discuss staff investigations).

97 U.S. CONST. art. I, § 1 (vesting all legislative powers in Congress); id. \$ 2, cl. 1 (providing that the House of Representatives "shall be composed of Members"); id. 
precise limits on how much power can be delegated are uncertain in this undeveloped area of constitutional law, certain points seem clear. On the one hand, a member cannot delegate to her staff central and important powers, such as her right to vote on bills or on matters such as impeachment. ${ }^{98}$ On the other hand, a member may authorize her staff to undertake significant tasks, such as researching and writing proposed legislation, so long as the member introduces the bill herself.

Despite the uncertainties in this area of constitutional law, the following division of labor between committee and staff appear to be clearly constitutional. The committee would determine which witnesses to depose and the general areas in which they would be examined. The staff would then depose the witnesses, deciding which particular questions within the area specified by the committee to ask. If a witness objected to a question from the staff, a member of the committee would then rule upon the objection. To enable members to rule without requiring that they incur the burden of attending the deposition, the members could be contacted by telephone or fax.

This arrangement would fall well within constitutional limits because the staff would not exercise discretion on significant policy matters. Rather, staff members could only ask questions within the general area specified by the committee. Moreover, a witness would be obliged to answer a question only if she did not object to it or a committee member ruled against the objection. ${ }^{99}$

\section{Providing Adequate Resources to the Committee}

Finally, the committee would need adequate resources to fund its

$\S 3$, cl. 1 (providing that the Senate "shall be composed of two Senators from each State").

${ }^{98}$ See John O. McGinnis \& Michael B. Rappaport, The Rights of Legislators and the Wrongs of Interpretation: A Further Defense of the Constitutionality of Legislative Supermajority Rules, 47 DUKE L.J. 327, 331-35 (1997).

${ }_{99}$ It might be argued that this arrangement would unduly burden committee members by requiring one of them to be available by telephone or fax when depositions are being taken. Because committee members could share the responsibilities, one might doubt that this arrangement would in fact be burdensome. If it were, however, alternative procedures could be employed. For example, the committee could require witnesses to answer questions asked by staff members, even if the witness has an objection (except in cases of self-incrimination, which raise additional concerns). The witness's answer, however, could not be used until a member of the committee ruled against the objection. This arrangement would still appear to be constitutional, because the witness's answer could not be used until a member of the committee had ruled. 
investigations. Unfortunately, Congress could not determine in advance how much money the committee would need for a given year due to the difficulty of predicting how many investigations would be required. This creates a dilemma. On the one hand, if Congress provides a small appropriation, the committee might need to secure additional funds from the parent house, which could then use its leverage to interfere with the committee's investigations. On the other hand, if the committee receives a large appropriation, it might be tempted to use the funds to investigate people even if the investigations were not warranted.

Congress could avoid this dilemma between conferring inadequate and excessive funds by providing the committee with a small appropriation along with the authority to access additional moneys if necessary. To secure the additional funds, the committee might be required to submit a written finding, to be sent to the parent house, explaining why they are needed. To ensure that the finding was not made too easily, a supermajority of the committee members might be required to support it. In this way, the committee could be given limited resources while retaining the ability to secure additional funds if circumstances required it.

\section{BENEFTTS OF THE PROPOSAL}

As a means of monitoring and disciplining executive misconduct, the congressional investigation proposal is superior to the Independent Counsel statute and to other types of investigations by the executive branch. Indeed, the congressional investigation proposal avoids each of the significant defects of the Independent Counsel statute. The proposal is constitutional, politically accountable, fair, and does not excessively burden the executive branch or employ a criminal prosecution model. Although not perfect, it is the best of the available alternatives.

First, the congressional investigation proposal conforms to the letter and spirit of the Constitution. The procedure relies upon clearly established constitutional powers of impeachment and oversight. Therefore, unlike the Independent Counsel statute and other types of independent executive branch investigations, the proposal need not infringe on the President's power to appoint or control executive officials in order to establish an effective investigative arrangement.

Second, the proposal employs officials who are both electorally accountable and independent of presidential control. The committee members would have to stand for election. Although the committee 
staff would not face the voters, the committee members would make the important policy decisions. The committee also would be entirely insulated from presidential control, since the members would not take orders from the President and would be part of a separate branch. By contrast, investigations by executive officials cannot be both independent and accountable: either the officials are independent of the President but not electorally accountable, or they are electorally accountable but subject to presidential control.

Third, the proposal establishes an investigative system that would operate fairly and reasonably. The interparty appointment process would ensure that the committee members would tend to have integrity and be moderate. ${ }^{100}$ Further, because the committee would investigate all executive officials who might have committed misconduct, not just one person, it would not have an incentive to find wrongdoing where none exists.

Fourth, the proposal avoids the problems caused by using criminal prosecutions to monitor and discipline executive officials. Congressional investigations would explore all significant wrongdoing, not simply criminal behavior, and they would not burden investigators with having to prove the allegations beyond a reasonable doubt in a criminal proceeding where the defendant enjoys significant privileges. Moreover, congressional investigations would not require that an official be criminally prosecuted and possibly imprisoned to ensure that she was held accountable for her actions.

Finally, the proposal does not excessively burden the executive branch and is unlikely to be used as a political weapon. Congressional investigations would not create a risk that the investigated official would be imprisoned or even suggest that she had committed a crime. Rather, such investigations would mainly serve to uncover information about misconduct and release it to the public. Moreover, congressional investigations would not, as mentioned above, provide the committee with an incentive to find that the investigated official had engaged in misconduct. Consequently, the burdens that congressional investigations impose on executive officials and the executive branch would be much smaller than those imposed by independent counsel investigations.

${ }^{100}$ That the committee members are electorally accountable also suggests that they would behave reasonably. 


\section{OTHER ASPECTS OF THE PROPOSAL}

Although I have described the essentials of the congressional investigation proposal, there are several other aspects that warrant discussion. In this Part, I discuss three questions: Should the investigative committee be placed in the House of Representatives, the Senate, or both? Would congressional investigations be as effective as investigations by the executive branch? Is there any chance that the majority party in Congress would be willing to enact this proposal?

\section{A. The Location of the Committee}

One important question is whether the specially appointed investigative committee should be located in the House, the Senate, or both chambers. The most obvious arrangement, based on existing practice, would be for each house to establish a separate committee. The main problem with separate committees, however, is coordinating their independent actions. If both the House and Senate committees were to investigate a matter, that might unduly burden witnesses who would have to answer questions twice. Moreover, one committee's investigation could interfere with the second committee's inquiry if, for example, the first committee granted immunity to a witness or recommended prosecution to the executive branch. The committees might be able to address these problems, however, by establishing an agreement or guidelines to coordinate their investigations. Moreover, even if there were coordination problems, one might argue that these would be outweighed by the benefits produced by competition between the committees.

If coordinating two committees were deemed to be a significant problem, Congress could establish a single investigative committee. This could be done in one of two ways. First, investigations might be assigned exclusively to one of the houses. Some might argue that the House of Representatives should conduct the investigations, because the House possesses the exclusive power to determine whether to impeach an official. Defenders of the Senate might counter, however, that the Senate possesses the power of oversight and has historically conducted effective investigations. ${ }^{101}$

Alternatively, Congress could establish a joint House-Senate investigative committee with half of the members from each chamber. The

${ }^{101}$ See GraBOW, supra note $34, \S \S 2.3,2.5$ (discussing successful Senate investigations of Teapot Dome and Watergate). 
houses have often formed joint committees when both chambers want to pursue a matter and to coordinate their actions. ${ }^{102}$ This joint committee would have the advantage of providing a coordinated investigation and allowing both houses to participate. One drawback of a joint committee, however, is that it might be more difficult to find a single committee structure acceptable to the political parties in both houses.

\section{B. The Effectiveness of the Committee}

One possible objection to the congressional investigation proposal is that it would not be as effective at uncovering information as executive branch investigations. Investigators need to be able to induce lower-level officials and others to provide information about wrongdoing by higher-level officials. Criminal prosecutors, the argument continues, would be able to secure more cooperation because they have both the stick of threatening to prosecute someone who does not cooperate as well as the carrot of providing immunity to someone who does. Congressional committees, on the other hand, can not criminally prosecute and therefore would have to rely entirely on the carrot of immunity.

While this objection is not without force, there is reason to believe that the committee would have adequate tools for uncovering information. Although the committee itself could not criminally prosecute, it could refer incriminating evidence to the executive branch with a strong recommendation that it prosecute. Although prosecutors might be hesitant to pursue a case that would further an investigation against executive officials, this reduced incentive could be addressed by a statute requiring the executive to justify in writing any decision it made not to prosecute. Additionally, the committee could use its powers to induce an individual to cooperate with its investigation. If an individual refused to cooperate, the committee could threaten to require her to publicly testify or to write a public report detailing her behavior. Such actions could significantly damage the individual's reputation. They might also increase the chances that the executive would prosecute her.

In addition to these powers, congressional investigations would have certain advantages over executive branch investigations. The congressional committee could secure information by offering immu-

${ }^{102}$ See id. $\S 2.6[\mathrm{~b}]$ (discussing the joint investigation and hearings conducted by the House and Senate Iran-Contra Committees); HOW CONGRESS WORKS, supra note 58, at 143. 
nity to the target of the investigation. Executive branch prosecutors would not use this tactic, because their main goal is to convict people who have violated the law. Congressional investigations, by contrast, are intended to uncover information rather than to prosecute individuals. Thus, the committee might be willing to offer immunity from criminal prosecution in exchange for the target admitting wrongdoing and resigning her position. Congressional investigations would also avoid having to comply with the strict requirements that govern criminal prosecutions, such as proof beyond a reasonable doubt and the various rights enjoyed by criminal defendants.

Finally, the members of the investigative committee may have strong political incentives to conduct an effective investigation. An investigation of a high executive official that leads to her dismissal is often a significant political event. Especially if the public regards it as fair, the investigation might significantly enhance the political reputations of the committee members. To mention just one example, Senator Sam Ervin went from being an ordinary U.S. Senator to a national symbol of integrity as a result of the Watergate investigation. The opportunity to gain public esteem would give members of the committee an incentive to vigorously pursue investigations-but only if their investigations were seen as legitimate.

In the end, there is a strong argument that congressional investigations would be at least as effective as executive investigations. But even if congressional investigations were a little less effective than executive investigations, it is not clear that this should be regarded as a significant defect. After years of overly aggressive independent counsels, less vigorous investigations might be just what the Republic needs.

\section{Incentives To Adopt the Proposal}

A final objection to the congressional investigation proposal is that, even if it would be good policy, it will never be enacted because it requires the majority party to voluntarily reduce its power. Under existing institutions, if the majority party deems the investigative committee to be sufficiently important, it has the option of appointing committee members who will reliably vote as the median voter of the party desires. ${ }^{103}$ By contrast, under the interparty appointment proc-

${ }^{103}$ That is, instead of appointing members who reflect the views of all of the party's members-the most extreme, the middle, and the most moderate-the majority party can appoint a group of members consisting only of the middle and the most extreme. 
ess, the committee would tend to be composed of the most moderate members of both parties and the balance of power would probably be held by the moderate members of the majority party. Thus, the median voter in the majority party would probably prefer the existing appointment method. Because the median voter of the majority party is normally positioned so that the leadership of the majority party reflects her preferences ${ }^{104}$ and because that leadership can largely prevent the congressional investigation proposal from being voted upon, ${ }^{105}$ one can predict that the majority party would not allow the congressional investigation proposal to be enacted. Since, according to this view, the proposal cannot be enacted, it is not worth discussing. ${ }^{106}$

This objection, however, is mistaken. Although the proposal would not clearly benefit existing powerholders, it would not clearly harm them either. Rather, its effects on existing powerholders would be mixed and would depend on public opinion, and therefore, are hard to predict. Depending on how the public and the different members of the majority coalition viewed the proposal, the majority coalition might actually support it.

There are several reasons why the majority party might support the proposal. First, although the proposal would impose costs on the majority party, it would also provide benefits. It is true that when

This group can then vote as a block to ensure that the committee consistently takes actions that the party's median members would desire.

${ }^{104}$ According to one influential theory within the field of positive political theory, the preferences of the median or middle voter will generally prevail in institutions that are subject to majority rule. See DENNIS C. MUELIER, PUBLIC GHOICE II, at 65-66 (1989).

${ }^{105}$ See HOW CONGRESS WORKS, supra note 58, at 69, 76, 89 (discussing how congressional leadership controls the legislative process).

${ }^{106}$ One might argue that the median voter in the entire house controls the house rather than the median voter of the majority party. If an ordinary bill were opposed by the median voter of the majority party, but had the support of the moderate members of that party and the entire minority party, it might pass. Why, then, would not the moderate members of the majority party join with the entire minority party to select members for the investigatory committee? There are many reasons why this would not happen; here, I will mention just one. In legislatures, certain votes are deemed to be matters of party loyalty. Practically, a party member cannot vote against the party's position and remain a member of the party in good standing. This would usually be true of a vote on committee memberships. See id. at 121 (describing the method for appointing committee members, which generally allows leadership to make the decisions); id. at 7 (describing actions leadership can take to punish disloyal members). Thus, the most moderate members of the majority party would be unlikely to defect from their party's position on this issue, except in the unlikely event that they believed the composition of this one committee was more important than their membership in good standing in the party. 
there is divided government, a specially appointed committee would probably investigate less aggressively than an ordinary committee controlled by the majority party. The actions that the specially appointed committee would take, however, would command wider support from the members of the committee and might even pass unanimously. Consequently, the committee's actions would have more credibility and therefore more influence with the public. Because the principal effect of a congressional investigation occurs through its influence on the public, the enhanced credibility of investigations by specially appointed committees would be a significant benefit to the majority party.

Second, the majority party would also benefit to the extent that voters believed the party had adopted a worthy proposal. That is, if the public favored the proposal, its passage by the majority party might increase the public's support for the party. ${ }^{107}$ Finally, the majority party might also adopt the proposal if the party believed it would be good public policy. Although politicians often take actions based on their interests, sometimes they act from their genuine beliefs about the public good. They are especially likely to do so when a measure's effects on their interests seem to be relatively neutral-which appears to be true of the congressional investigation proposal.

Thus, there is a reasonable chance that a majority party might choose to support the proposal, and therefore, one cannot dismiss it as utopian. Indeed, because the probability of its enactment depends in part on how the public views it, there is all the more reason to examine the public policy arguments for adopting it.

\section{CONCLUSION}

Now that the nation has apparently discarded the Independent Counsel statute, with what should we replace it? While most commentators propose that the executive branch investigate itself, this Essay argues that Congress should investigate executive wrongdoing.

Although the existing congressional investigation process is flawed, it can be improved. Congress should establish a committee with the sole function of investigating executive branch misconduct. Because it is essential that the committee not spend its time engaged

${ }^{107}$ The public might be especially grateful at a time when the nation professes to be weary from the partisan fights that occurred during the investigation and impeachment of President Clinton. See David S. Broder \& Dan Balz, A Year of Scandal with No Winners, WASH. POST, Feb. 11, 1999, at Al. 
in partisan disputes, each political party should choose the committee members from the opposing party.

Congress should also provide the investigative committee with adequate powers. The committee should be empowered to bring a civil action in federal court in order to enforce its subpoenas. The committee should also have the power to allow its staff to question witnesses who are under oath so that committee members are not overly burdened by their investigative duties.

This congressional investigative system would be superior to executive branch investigations. Under this system, the persons conducting the investigation would be both independent of presidential control and accountable to the voters. The committee members would also tend to be political moderates and to have integrity. In addition, the system would not give the investigators an undue incentive to find that the targets of the investigation were guilty. Finally, congressional investigations would avoid the many problems created when criminal prosecutions are used to monitor executive misconduct.

Although the original Constitution envisioned that Congress would monitor and remedy executive misconduct, modern innovations have led to a system that relies primarily on executive branch investigations. It is now time to return to the Constitution's approach and to construct an investigative system based on it. As is so often the case, we do best when we build on the foundations erected by the Framers. 
